\title{
X-linked central congenital hypothyroidism with late-onset testicular enlargement
}

INSERM

\section{Source}

INSERM. (1999). Orphanet: an online rare disease and orphan drug data base. $\underline{X \text {-linked }}$ central congenital hypothyroidism with late-onset testicular enlargement.

ORPHA:329235

X-linked central congenital hypothyroidism with late-onset testicular enlargement is a rare, genetic, endocrine disease characterized by central hypothyroidism, testis enlargement in adolescence resulting in adult macroorchidism, delayed pubertal testosterone rise with a subsequent delayed pubertal growth spurt, small thyroid gland, and variable prolactin and growth hormone deficiency. 